\title{
The Relationship Between Compulsive Internet Use and Symptoms of Depression and Anxiety in Adolescence
}

\author{
Tena Erceg ${ }^{1}$, Gordana Buljan Flander², Tea Brezinšćak ${ }^{2}$ \\ ${ }^{1}$ Kindergarten "Konavle", Cavtat, Croatia, ${ }^{2}$ Child and Youth Protection Center of Zagreb, \\ Zagreb, Croatia
}

\begin{abstract}
Difficulties in managing one's habits of internet use have been the focus of much clinical and scientific interest in the past twenty years. However, their definition, clinical nature, and relationships with other relevant concepts, remain a matter of controversy. The aim of this study was to examine the relationship between compulsive internet use (CIU) and symptomatology related to depression and anxiety among adolescents. The sample consisted of 1320 primary and secondary school students aged 11 to 18 years. Problematic patterns of internet use were assessed using the Compulsive Internet Use Scale, while depression and anxiety symptoms were measured using Beck Youth Depression Inventory and Beck Youth Anxiety Inventory. The results have shown that adolescents who report more compulsive patterns of internet use also show higher levels of depression and anxiety symptoms. The findings contribute to the understanding of problematic internet use in adolescents and its relationship with internalizing emotional difficulties, which suggests valuable implications for the development of prevention and intervention programs within the adolescent population.
\end{abstract}

Key words: Internet, addictive behavior, anxiety, depression, adolescents

Copyright (C) 2018 KBCSM, Zagreb

e-mail: alcoholism.kbcsm@gmail.com•www.http://apr.kbcsm.hr

\section{Introduction}

Internet has introduced a new dimension to the environment in which children and youth master their developmental tasks. For adolescents internet has become an important source of leisure activities [1], and the leading mean of communicating with peers

Correspondence to: Tena Erceg

Kindergarten "Konavle"

Put od Cavtata bb, 20210 Cavtat

E-mail: tena.erceg1@gmail.com

Tel: +385981960035
[2-4]. Although it has created many opportunities for children and adolescents, it also presents a source of significant risks, among which this study has focused on compulsive internet use. Despite the lack of consensus among researchers on the nature, terminology and definition of the underlying concept [5], numerous authors agree that internet users can develop problematic patterns of internet use, characterized by obsessive and compulsive behavior negatively affecting daily functioning [6-15]. 
This study relies on the concept of compulsive internet use [16], developed by Meerkerk et al. [17] based on diagnostic criteria for dependence and pathological gambling [18], conceptualization of behavioral addictions formulated by Griffiths [19], and the results of previous research conducted by Meerkerk, Laluan, \& Eijnden [20]. The authors propose that the source of addictive potential is not internet itself, but rather certain online activities, the use of which results in compulsive internet use [16]. Meerkerk et al. [17] have defined compulsive internet use as a one-dimensional phenomenon, which consists of: 1) loss of control, defined as spending more time online than intended and unsuccessful attempts to diminish use of internet ; 2) mental and behavioral preoccupation with internet use (thinking about internet when offline and preference for internet use above other activities), 3) withdrawal symptoms, defined as feelings of unrest and agitation when an individual is unable to go online; 4) using internet to relief negative affective states, 5) conflict with others and intrapersonal conflicts (guilt and remorse).

Adolescents have been identified as a group at heightened risk for development of problematic internet use $[21,22]$. Their vulnerability has been attributed to lack of emotional and psychological maturity [23], insufficiently developed self control and cognitive abilities [24], heightened sensitivity [16], and lack of online parental monitoring [25].

Excessive and/or compulsive patterns of internet use among children and youth have been linked to diminished psychological wellbeing, in terms of both emotional [4, 26-32] and behavioral difficulties [26, 32, 33]. The cognitive-behavioral model of pathological internet use (PIU) by Davis [34-38], views psychosocial problems as components in its etiology, suggesting that mental health difficulties make the individual more susceptible to PIU, by contributing to the development of maladaptive cognitions about self and the world, which, joined with lack of social support and social isolation, lead to the development and maintaining of PIU, and are further strengthened through PIU related behaviors, such as social isolation due to excessive time spent online. Although Davis` [34] model does not consider the reverse effect of the PIU symptoms and maladaptive cognitions on psychosocial problems, individuals with diminished psychosocial wellbeing seem to be inclined to developing a preference for online social interaction, which is connected with development of negative outcomes associated with problematic internet use [3537]. Further, negative outcomes of compulsive internet use, such as neglect of work, school, or significant relationships use, have been shown to contribute to impairment in individuals`s psychosocial wellbeing $[39,40]$.

Based on critical review of current research on the relationship between pathological internet use and comorbid psychopatology, Carli et al. [41] conclude that depression shows the strongest correlation with pathological internet use. Depression related symptomatology has been linked to problematic patterns of internet use in both cross-sectional [29, 32, 42-44] and longitudinal studies [22, 45, 46]. However, multiple studes contradict the predominant conclusions [47-49], which suggests the need for further research, and calls for clarification of the underlying constructs and moderating variables, which could explain the discrepancies in the findings.

Research on the relationship between anxiety and problematic internet use is predomi- 
nantly focused on social anxiety, which has systematically been linked to problematic internet use [32, 35, 48-51]. However, research focused on anxiety symptomatology in general in adolescent population is scarce and inconsistent. Durkee [42] and Xiuqin et al. [31] have found that adolescents with problematic internet use patterns show higher levels of anxiety, which has also been found in college students [44, 52]. However, in a prospective study conducted by Lam \& Peng [46] no significant relationship between pathological use of the internet and anxiety at the time of follow up was observed, suggesting no effect of pathological internet use on the wellbeing of participants.

The current body of research is also marked by the discrepancies among numerous concepts developed to describe maladaptive patterns of internet use, thus limiting the validity and comparability of previous findings. Further, given that a significant number of studies has been conducted in a different cultural setting, it is unclear whether obtained results can be generalized on Croatian adolescents. In this regard the present study contributes to previous research as the first study on compulsive internet use conducted on a large nation wide sample of Croatian adolescents.

The aim of this study was to determine whether depression and anxiety symptoms can be predicted based on the level of compulsive internet use among adolescents. It was hypothesized that emotional difficulties will be more pronounced among adolescents who exhibit more compulsive patterns of internet use. Given that levels of depression and anxiety symptoms have been shown to change through childhood and adolescence [53-55], differ among adolescent boys and girls $[54,56]$, and vary depending on school performance $[54,57,58]$, the effects of these variables have been controled.

\section{Methodology}

\section{Subjects}

Research was conducted on a convenient sample of 1320 primary and secondary school (both grammar and vocational) students from different Croatian regions. The participants included children from $5^{\text {th }}$ grade of primary schools to $2^{\text {nd }}$ grade of secondary schools, ranging from 11 to 18 years of age $(M=14.57 ; S D=1.67)$, and relatively equable in gender (43\% of boys, $57 \%$ of girls).

\section{Materials and methods}

Compulsive Internet use. The level of addiction related behavior and experiences in participants internet use was assessed using the Compulsive Internet Use Scale (CIUS) [17]. CIUS is a self-report measure, scored on a five point Likert scale ranging from 0 ("never") to 4 ("very often"), which consists of 14 questions focused on maladaptive patterns of internet use as defined by Meerkerk et al. [17]. Previous studies have shown CIUS to have good factorial stability across time and samples, high internal consistency and high correlations with concurrent and criterion variables [17]. Current study has confirmed the single factor structure of the scale, with items ranging from moderate to strong factor loadings (.599 to .759), as well as high internal consistency (Cronbach $\alpha=.912$ ).

Anxiety and depression. Children`s emotional difficulties were evaluated using Beck Youth Depression Inventory (BDI-Y) and Beck Youth Anxiety Inventory (BAI-Y) [59]. Both instruments are 20 item self-report measures, designed to evaluate emotional impairment 
of children between ages of 7 and 18. The children are asked to describe the frequency of anxiety and depression related thoughts, feelings and behaviors during the past two weeks, on a four point scale ranging from 0 ("never") to 3 ("always"). For the purposes statistical analyses sum of scores on each of the traits were used, with higher results indicate greater levels of symptomatology. Both instruments have shown high internal consistency and high convergent validity [59, 60].

Sociodemographic data. The participants also answered a short sociodemographic questionnaire, containing questions about gender, age and school performance, measured as grade average at the end of semester.

\section{Procedure}

The data was gathered within the framework of a research project on experiences and behaviors of children and youth on Facebook social network, conducted by Brave Phone and Child and Youth Protection Center of Zagreb in 2013. Research was approved by the Ministry of Social Politics and Youth and the Ethical Commitee of Child and Youth Protection Center of Zagreb. Written con- sent of headmasters and parents was obtained, and the participation of children was voluntary. The questionnaires were administered in a group setting by trained volunteers. Research was conducted in accordance with Ethical codex of research with children [61].

\section{Results}

Descriptive statistics and intercorrelations are presented in Table 1. Adolescents with higher levels of CIU exhibited higher levels of symptomatology related to depression $(r$ $=.415 ; p<.01)$ and anxiety $(r=.369 ; p<$ $.01)$. CIU also showed correlations with age, gender and school performance, albeit very weak, suggesting older $(\mathrm{r}=.169 ; \mathrm{p}<.01)$ and female adolescents $(r=.123 ; p<.01)$, as well as those with lower grades $(r=-.172$; p $<.01$ ), to be at risk for CIU. An examination of correlations revealed that intercorrelations between independent variables were very weak.

The contribution of CIU in predicting depression and anxiety among adolescents was examined by conducting two stage hierarchical multiple regressions, separately for depression and anxiety as dependent variables.

Table 1. Descriptive statistics and intercorrelations $(\mathrm{N}=1317)$

\begin{tabular}{|c|c|c|c|c|c|c|c|c|}
\hline Variable & M & SD & 1. & 2. & 3. & 4. & 5. & 6 \\
\hline 1. Gender ${ }^{a}$ & 1.57 & 0.50 & 1 & & & & & \\
\hline 2. Age & 14.57 & 1.67 & .037 & 1 & & & & \\
\hline 3. School performance ${ }^{b}$ & 4.25 & 0.69 & $.106^{* * *}$ & $-.322 * * *$ & 1 & & & \\
\hline 4. Compulsive Internet use & 29.52 & 11.13 & $.123^{* * *}$ & $.168^{* * *}$ & $-.17 * * *$ & 1 & & \\
\hline 5. Anxiety & 19.17 & 9.42 & $.261 * * *$ & .042 & $-.116^{* * *}$ & $.368^{* * *}$ & 1 & \\
\hline 6. Depression & 11.42 & 8.95 & $.249^{* * *}$ & .031 & $-.128^{* * *}$ & $.415^{* * *}$ & $.718^{* * *}$ & 1 \\
\hline
\end{tabular}

$*_{p}<.05,{ }^{* *} p<.01, * * * p<.001$.

${ }^{\mathrm{a}} 1=$ male, $2=$ female.

b1 $=$ insufficient, $2=$ sufficient, $3=$ good, $4=$ very good, $5=$ excellent. 
Table 2. Summary of hierarchical regression analysis in predicting depression $(N=1319)$

\begin{tabular}{lcc}
\hline & \multicolumn{2}{c}{ Standardized Regression Coefficients $(\beta)$} \\
\cline { 2 - 3 } Predictors & Step 1 & Step 2 \\
\hline Gender $^{\mathrm{a}}$ & $.268^{* * *}$ & $.217^{* * *}$ \\
Age & -.033 & $-.077^{* *}$ \\
School performance & $-.167^{\mathrm{b} * *}$ & $-.110^{* * *}$ \\
Compulsive Internet use & & $.382^{* * *}$ \\
& & \\
Model summary & & .474 \\
$\mathrm{R}$ & .295 & $.222^{* * *}$ \\
Adjusted $\mathrm{R}^{2}$ & $.085^{* * *}$ & $.137^{* * *}$ \\
Delta $\mathrm{R}^{2}$ & $.087^{* * *}$ & \\
\hline
\end{tabular}

${ }^{*} p<.05,{ }^{* *} p<.01,{ }^{* * *} p<.001$.

${ }^{\mathrm{a}} 1=$ male, $2=$ female.

${ }^{\mathrm{b}} 1=$ insufficient, $2=$ sufficient, $3=\operatorname{good}, 4=$ very good, $5=$ excellent.

Table 3. Summary of hierarchical regression analysis in predicting anxiety $(\mathrm{N}=1320)$

\begin{tabular}{lcc}
\hline & \multicolumn{2}{c}{ Standardized Regression Coefficients $(\beta)$} \\
\cline { 2 - 3 } Predictors & Step 1 & \multicolumn{1}{c}{ Step 2} \\
\hline Gender & $.277^{* * *}$ & $.232^{* * *}$ \\
Age & -.015 & $-.054^{*}$ \\
School performance & $-.152^{* * *}$ & $-.102^{* * *}$ \\
Compulsive Internet use & & $.332^{* * *}$ \\
Model summary & & \\
R & & \\
Adjusted $\mathrm{R}^{2}$ & .299 & .439 \\
Delta $\mathrm{R}^{2}$ & $.087^{* * *}$ & $.190^{* * *}$ \\
\hline
\end{tabular}

${ }^{*} p<.05,{ }^{* *} p<.01,{ }^{* * *} p<.001$.

${ }^{\mathrm{a}} 1=$ male, $2=$ female.

${ }^{\mathrm{b}} 1=$ insufficient, $2=$ sufficient, $3=$ good, $4=$ very good, $5=$ excellent.

In the first stage of both models the entered predictor variables included gender, age and school performance, which were considered to be control variables, while at stage two CIU was included among the predictor variables (Table 2 and Table 3). 
The hierarchical multiple regression revealed that at stage one, gender, age and school performance contributed significantly to the prediction of both depression $(F(3,1315)=41.740, p<.001)$ and anxiety $(F(3,1316)=42.936, p<.001)$, accounting for equal levels $(9 \%)$ of both depression and anxiety symptoms. In the second stage of the models, compulsive internet use was shown to predict both depression $(F(4,1314)$ $=95.005, p<.001)$ and anxiety $(F(4,1315)$ $=78.556, p<.001)$ levels above and beyond control variables, explaining an additional $14 \%$ of variation of depression and $10 \%$ of variation in anxiety symptomatology. In both models, CIU was the strongest predictor, positively correlated with depression $(\beta$ $=.382 ; p<.001)$ and anxiety $(\beta=.332 ; p<$ $.001)$, suggesting that adolescents who exhibit more compulsive patterns of internet use show higher levels of depression and anxiety symptoms.

\section{Discussion}

Research on the relationship between excessive and/or compulsive internet use and psychological wellbeing has been strongly influenced by discrepancies among conceptual definitions of the underlying construct. This study relied on the previously described concept of compulsive internet use, which has been widely researched, and is accompanied by a psychometrically sound measure [16, 17]. The aim of this study was to determine whether anxiety and depression in adolescents can be predicted based on compulsive internet use. As hypothesized, compulsive internet use was linked with higher levels of anxiety and depression symptoms.

An overview of available research suggests that the inconsistency of previous findings could be attributed to differences in the operationalization of the underliying construct. It supports the notion that is not the mere amount of time spent online [47-49] but the compulsive and/or addictive nature related to heavy internet use, that is connected to diminished emotional wellbeing [33, 44, 62-65].

Regarding the relationship of CIU and anxiety, unlike previous research, which has mainly focused on anxiety related to social functioning, the present study examined the relationship of compulsive internet use and cognitive, emotional and behavioral aspects of anxiety in general. Findings suggest that other aspects of anxiety (e.g. such as worrying about one`s physical and psychological integrity, school performance or future, physiological symptoms of anxiety or specific fears), can also be found among adolescents using internet in a compulsive manner, which is in accordance with findings of previous studies conducted on older samples [44, 52]. These results call for further research and development of the present theoretical model, which has viewed cyberspace merely as a facilitator of social interactions for shy and socially anxious individuals $[66,67]$, which stimulates preference for online communication and potentially leads to problematic patterns of internet use [36].

Current study does not allow conclusions about the causality of the relationship between emotional wellbeing and problematic internet use. Previous findings explaining this relationship are scarce, suggesting the need for further research. Some studies suggest that psychosocial problems contribute to the vulnerability in developing problematic, compulsive and/or addictive patterns of internet use [42, 64, 65], which is also suggested by the previously described cognitive-behavioral model of PIU [34]. 
However, although Davis' [34] model does not consider the reverse effect, several studies have indicated that PIU could increase the risk of diminished emotional wellbeing. In accordance with this hypothesis, Dong, Lu, Zhou and Zhao [40] have found that certain psychopathological disorders and traits, including depression and anxiety, occurred as outcomes of internet addiction disorder. Furthermore, negative outcomes of compulsive internet use, such as neglect of work, school, or significant relationships use, have been shown to contribute to impairment in individuals 's psychosocial wellbeing [38, 68]. A longitudinal study by Gámez-Guadix et al. [68] has linked depressive symptoms with an increase in preference for online relationships, use of the internet for mood regulation, and negative outcomes, while present negative outcomes have predicted an increase in depressive symptoms, suggesting a bidirectional relationship.

Moreover, it is also possible that both phenomena may be different manifestations of one (underlying) psychological disorder or personality trait, such as obsessive-compulsive symptoms [40], deficient self regulation

\section{References}

1. Smahel D, Brown BB, Blinka L. Associations between online friendship and Internet addiction among adolescents and emerging adults. Dev Psychol. 2012;48:381.

2. Gross EF. Adolescent Internet use: What we expect, what teens report. J Appl Dev Psychol. 2004;25:633-49.

3. O'Keeffe GS, Clarke-Pearson K. The impact of social media on children, adolescents, and families. Pediatrics. 2011;127:800-4. or impulsivity $[68,69]$, or low emotional stability [30].

Despite the limitations, current findings have significant implications for the development of efficient prevention and intervention programs, as well as empirical value in the clinical setting. By connecting compulsive internet use with depression and anxiety, attention is drawn to the need to assess and address patterns of internet use and associated risks in adolescents seeking help for emotional difficulties, as well as addressing possible underlying or comorbid emotional difficulties in adolescents exhibiting problematic internet use. Further, these findings present the first national study conducted among Croatian adolescents, conducted on a large sample and contribute to the body of research focused on adolescent population, which has been shown to be vulnerable to problematic patterns of internet use.

\section{Acknowledgments}

None

\section{Conflict of interest}

None to declare
4. Van den Eijnden RJ, Meerkerk GJ, Vermulst AA, Spijkerman R, Engels RC. Online communication, compulsive Internet use, and psychosocial well-being among adolescents: a longitudinal study. Dev Psychol. 2008;44:655.

5. Anderson EL, Steen E, Stavropoulos V. Internet use and Problematic Internet Use: a systematic review of longitudinal research trends in adolescence and emergent adulthood. Int J Adolesc Youth. 2017;22:430-54.

6. Bernardi S, Pallanti S. Internet addiction: a descriptive clinical study focusing on comorbidities 
and dissociative symptoms. Compr Psychiatry. 2009;50:510-6.

7. Block JJ. Issues for DSM-V: Internet addiction. Am J Psychiatry. 2008;165:306-7.

8. Cash H, D Rae C, H Steel A, Winkler A. Internet addiction: A brief summary of research and practice. Curr Psychiatry Rev. 2012;8:292-8.

9. Kuss DJ. Internet gaming addiction: current perspectives. Psychol Res Behav Manag. 2013;6:12537.

10. Kuss DJ, Griffiths MD. Internet gaming addiction: A systematic review of empirical research. Int J Ment Health Addict. 2012;10:278-96.

11. Shapira NA, Lessig MC, Goldsmith TD, Szabo ST, Lazoritz M, Gold MS, et al. Problematic internet use: proposed classification and diagnostic criteria. Depress Anxiety. 2003;17:207-16.

12. Suler JR. To get what you need: healthy and pathological Internet use. Cyberpsychol Behav. 1999; 2:385-93.

13. Tao R, Huang X, Wang J, Zhang H, Zhang Y, Li M. Proposed diagnostic criteria for internet addiction. Addiction. 2010;105:556-64.

14. Widyanto L, Griffiths M. 'Internet addiction': a critical review. Int J Ment Health Addict. 2006;4:3151.

15. Young KS. Internet addiction: The emergence of a new clinical disorder. Cyberpsychol Behav. 1998;1:237-44.

16. Meerkerk GJ. Pwned by the internet. Explorative research into the causes and consequences of compulsive internet use (thesis). Rotterdam: Erasmus University; 2007.

17. Meerkerk GJ, Van Den Eijnden RJ, Vermulst AA, Garretsen HF. The compulsive internet use scale (CIUS): some psychometric properties. Cyberpsychol Behav. 2009;12:1-6.

18. American Psychiatric Association. Diagnostic and Statistical Manual of Mental Disorders DSM IIIR, American Psychiatric Association, Washington, 1987.

19. Griffiths M. Internet addiction: fact or fiction? The Psychologist. 1999;12:246-50.

20. Meerkerk, G., Laluan, A. M. E., Eijnden, R. J. J. M. (2003). Internetverslaving: hoax of serieuze bedreiging voor de geestelijke volksgezondheid? [Internet addiction: hoax or serious threat for public mental health?] (Vol. 30). Rotterdam: IVO.
21. Bakken IJ, Wenzel HG, Götestam KG, Johansson A, Øren A. Internet addiction among Norwegian adults: a stratified probability sample study. Scand J Psychol. 2009;50:121-7.

22. Van den Eijnden RJ, Meerkerk GJ, Vermulst AA, Spijkerman R, Engels RC. Online communication, compulsive Internet use, and psychosocial well-being among adolescents: a longitudinal study. Dev Psychol. 2008;44:655.

23. Kelleci M, Inal S. Psychiatric symptoms in adolescents with Internet use: comparison without Internet use. Cyberpsychol Behav Soc Netw. 2010;13:191-4.

24. Xu J, Shen LX, Yan CH, Hu H, Yang F, Wang L, et al. Personal characteristics related to the risk of adolescent internet addiction: a survey in Shanghai, China. BMC Public Health. 2012;12:1106.

25. Kaltiala-Heino R, Lintonen T, Rimpelä A. Internet addiction? Potentially problematic use of the Internet in a population of $12-18$ year-old adolescents. Addict Res Theory. 2004;12:89-96.

26. Caplan S, Williams D, Yee N. Problematic Internet use and psychosocial well-being among $\mathrm{MMO}$ players. Comput Human Behav. 2009;25:1312-9.

27. Cheung LM, Wong WS. The effects of insomnia and internet addiction on depression in Hong Kong Chinese adolescents: an exploratory crosssectional analysis. J Sleep Res. 2011;20:311-7.

28. Fu KW, Chan WS, Wong PW, Yip PS. Internet addiction: prevalence, discriminant validity and correlates among adolescents in Hong Kong. Br J Psychiatry. 2010;196:486-92.

29. Kaess M, Durkee T, Brunner R, Carli V, Parzer P, Wasserman C, et al. Pathological Internet use among European adolescents: psychopathology and self-destructive behaviours. Eur Child Adolesc Psychiatry. 2014;23:1093-102.

30. Meerkerk GJ, Van den Eijnden RJ, Vermulst AA, Garretsen HF. The Relationship between Personality, Psychosocial Wellbeing and Compulsive Internet Use: The Internet as Cyber Prozac? In: Meerkerk, editor. Pwned* by the Internet. Explorative research into the causes and consequences of compulsive internet use. Rotterdam: IVO, 2007.

31. Xiuqin H, Huimin Z, Mengchen L, Jinan W, Ying Z. Ran T. Mental health, personality, and parental rearing styles of adolescents with Internet addiction disorder. Cyberpsychol Behav Soc Netw. 2010;13:401-6. 
32. Yen JY, Ko CH, Yen CF, Wu HY, Yang MJ. The comorbid psychiatric symptoms of Internet addiction: attention deficit and hyperactivity disorder (ADHD), depression, social phobia, and hostility. J Adolesc Health. 2007;41:93-8.

33. Evren C, Dalbudak E, Evren B, Demirci AC. High risk of internet addiction and its relationship with lifetime substance use, psychological and behavioral problems among 10th grade adolescents. Psychiatr Danub. 2014;26:330-9.

34. Davis RA. A cognitive-behavioral model of pathological Internet use. Comput Human Behav. 2001;17:187-95.

35. Caplan SE. Problematic Internet use and psychosocial well-being: development of a theory-based cognitive-behavioral measurement instrument. Comput Human Behav. 2002;18:553-75.

36. Caplan SE. Preference for online social interaction: A theory of problematic Internet use and psychosocial well-being. Communic Res. 2003;30:625-48.

37. Caplan SE. Theory and measurement of generalized problematic Internet use: A two-step approach. Comput Human Behav. 2010;26:1089-97.

38. Kim J, LaRose R, Peng W. Loneliness as the cause and the effect of problematic Internet use: The relationship between Internet use and psychological well-being. Cyberpsychol Behav. 2009;12:451-5.

39. Gámez-Guadix M. Depressive symptoms and problematic Internet use among adolescents: Analysis of the longitudinal relationships from the cognitive-behavioral model. Cyberpsychol Behav Soc Netw. 2014;17:714-9.

40. Dong G, Lu Q, Zhou H, Zhao X. Precursor or Sequela: pathological disorders in people with Internet addiction disorder. PloS one. 2011;6:e14703.

41. Carli V, Durkee T, Wasserman D, Hadlaczky G, Despalins R, Kramarz E, et al. The association between pathological internet use and comorbid psychopathology: a systematic review. Psychopathology. 2013;46:1-3.

42. Durkee T. Pathological Internet use and psychopathology among European adolescents (thesis). Stockholm: Karolinska Institutet; 2017.

43. Müller KW, Ammerschlaeger M, Freisleder FJ, Beutel ME, Woelfling K. Addictive internet use as a comorbid disorder among clients of an adolescent psychiatry-prevalence and psychopathological symptoms. Z Kinder Jugendpsychiatr Psychother. 2012;40:331-7.

44. Akin A, Iskender M. Internet addiction and depression, anxiety and stress. Int Online J Educ Sci. 2011;3:138-48.

45. Gámez-Guadix M. Depressive symptoms and problematic Internet use among adolescents: Analysis of the longitudinal relationships from the cognitive-behavioral model. Cyberpsychol Behav Soc Netw. 2014;17:714-9.

46. Lam LT, Peng ZW. Effect of pathological use of the internet on adolescent mental health: a prospective study. Arch Pediatr Adolesc Med. 2010;164:901-6.

47. Gross EF, Juvonen J, Gable SL. Internet use and well-being in adolescence. J Soc Issues. 2002;58:7590.

48. Kraut R, Kiesler S, Boneva B, Cummings J, Helgeson V, Crawford A. Internet paradox revisited. J Soc Issues. 2002;58:49-74.

49. Sanders CE, Field TM, Miguel D, Kaplan M. The relationship of Internet use to depression and social isolation among adolescents. Adolescence. 2000;35:237.

48. Caplan SE. Relations among loneliness, social anxiety, and problematic Internet use. Cyberpsychol Behav. 2006;10:234-42.

49. Chak K, Leung L. Shyness and locus of control as predictors of internet addiction and internet use. Cyberpsychol Behav. 2004;7:559-70.

50. Lee BW, Stapinski LA. Seeking safety on the internet: Relationship between social anxiety and problematic internet use. J Anxiety Disord. 2012; 26:197-205.

51. Liu CY, Kuo FY. A study of Internet addiction through the lens of the interpersonal theory. Cyberpsychol Behav. 2007;10:799-804.

52. Azher M, Khan RB, Salim M, Bilal M, Hussain A, Haseeb M. The relationship between internet addiction and anxiety among students of University of Sargodha. Int J Humanit Soc Sci. 2014;4:288-93.

53. Mazzone L, Ducci F, Scoto MC, Passaniti E, D'Arrigo VG, Vitiello B. The role of anxiety symptoms in school performance in a community sample of children and adolescents. BMC Public Health. 2007;7:347.

54. Twenge JM, Nolen-Hoeksema S. Age, gender, race, socioeconomic status, and birth cohort dif- 
ference on the children's depression inventory: A meta-analysis. J Abnorm Psychol. 2002;111:578.

55. Weems CF, Costa NM. Developmental differences in the expression of childhood anxiety symptoms and fears. J Am Acad Child Adolesc Psychiatry. 2005;44:656-63.

56. Lewinsohn PM, Gotlib IH, Lewinsohn M, Seeley JR, Allen NB. Gender differences in anxiety disorders and anxiety symptoms in adolescents. J Abnorm Psychol. 1998;107:109.

57. Fröjd SA, Nissinen ES, Pelkonen MU, Marttunen MJ, Koivisto AM, Kaltiala-Heino R. Depression and school performance in middle adolescent boys and girls. J Adolesc. 2008;31:485-98.

58. Tomljenović Ž, Nikčević-Milković A. Samopoštovanje, anksioznost u ispitnim situacijama i školski uspjeh kod djece osnovnoškolske dobi. Suvremena psihologija. 2005;8:51-62.

59. Beck JS, Beck AT, Jolly JB i Steer RA. Beckov inventar za djecu i adolescente. Priručnik. Jastrebarsko: Naklada Slap; 2011.

60. Matešić K, Ružić V, Matešić K. The Croatian standardization of the Beck Youth Inventory (BYI-II). In Dani Ramira i Zorana Bujasa (19; 2009); 2009.

61. Ajduković M, Kolesarić V. Etički kodeks istraživanja s djecom. Zagreb: Državni zavod za zaštitu obitelji, materinstva i mladeži i Vijeće za djecu Vlade Republike Hrvatske; 2003.
62. Ha JH, Kim SY, Bae SC, Bae S, Kim H, Sim M, et al. Depression and Internet addiction in adolescents. Psychopathology. 2007;40:424-30.

63. Tsitsika A, Critselis E, Louizou A, Janikian M, Freskou A, Marangou E, et al. Determinants of Internet addiction among adolescents: a case-control study. Sci World J. 2011;11:866-74.

64. Young KS, Rogers RC. The relationship between depression and Internet addiction. Cyberpsychol Behav. 1998;1:25-8.

65. Leung L. Stressful life events, motives for Internet use, and social support among digital kids. Cyberpsychol Behav. 2006;10:204-14.

66. Baker LR, Oswald DL. Shyness and online social networking services. J Soc Pers Relat. 2010;27:873-89.

67. Erwin BA, Turk CL, Heimberg RG, Fresco DM, Hantula DA. The Internet: home to a severe population of individuals with social anxiety disorder? J Anxiety Disord. 2004;18:629-46.

68. Gámez-Guadix M, Calvete E, Orue I, Las Hayas C. Problematic Internet use and problematic alcohol use from the cognitive-behavioral model: A longitudinal study among adolescents. Addict Behav. 2015;40:109-14.

69. Meerkerk GJ, Van den Eijnden RJ, Franken IH, Garretsen HF. Is compulsive internet use related to sensitivity to reward and punishment, and impulsivity? Comput Human Behav. 2010;26:729-35.

\section{Odnos između kompulzivne uporabe interneta i simptoma depresije i tjeskobe $u$ adolescenciji}

Sažetak - Teškoće u upravljanju navikama korištenja interneta tijekom posljednjih dvadeset godina predmet su značajnog kliničkog i znanstvenog interesa. Međutim, njihova definicija, klinička priroda i odnosi s drugim relevantnim konceptima i dalje su područja obilježena neslaganjem. Cilj ovog istraživanja bio je ispitati odnos između kompulzivnog korištenja interneta (KKI) i simptomatologije povezane s depresivnošću i anksioznošću među adolescentima. U istraživanju je sudjelovalo 1320 učenika osnovnih i srednjih škola, u dobi od 11 do 18 godina. Problematični obrasci korištenja interneta procjenjivani su pomoću Skale kompulzivnog korištenja Interneta, dok je depresivna i anksiozna simptomatologija mjerena pomoću Beckovog inventara depresivnosti za mlade i Beckovog inventara anksioznosti za mlade. Rezultati pokazuju da adolescenti koji izvještavaju o kompulzivnijim obrascima korištenja interneta također pokazuju više razine depresivne i anksiozne simptomatologije. Nalazi doprinose razumijevanju problematičnog korištenja interneta kod adolescenata te 
njegovog odnosa s internalizirajućim emocionalnim teškoćama, što predstavlja vrijedne implikacije za razvoj programa prevencije i intervencije namijenjenih adolescentskoj populaciji.

Ključne riječi: Internet, ovisničko ponašanje, anksioznost, depresivnost, adolescenti 
